\title{
Analysis on the Normative Factors Affecting the Online Food Delivery (OFD) Preference of Customers
}

\author{
MA. VICTORIA C. GANNABAN \\ College of Business Entrepreneurship and Accountancy, CAGAYAN STATE UNIVERSITY - ANDREWS CAMPUS, \\ Philippines, ambicjannie@gmail.com \\ DOI: 10.29322/IJSRP.11.11.2021.p11957 \\ http://dx.doi.org/10.29322/IJSRP.11.11.2021.p11957
}

\begin{abstract}
The purpose of the study is to determine the online food delivery profile of the respondents and its relationship to the normative factors affecting their online food delivery (OFD) preference. The study also ascertained a significant difference among the normative factors affecting respondents' online food delivery food preference when grouped according to their preferred online food delivery courier. The study was guided by three (3) null hypotheses. Moreover, the descriptive correlational method, which involves collecting and analyzing data using a questionnaire floated via google form to all the BSBA major in Marketing Management students of Cagayan State University, Andrews Campus. Purposive sampling was used.

On the other hand, frequency count and the percentage were utilized to categorize the online food delivery profile of the respondents. For the degree of influence on the normative factors affecting the online food delivery preference of the respondents, the Likert Scale Value was assigned. Chi-square was used to test the significant relationship between the online food delivery profile and the normative factors. ANOVA was utilized to determine the significant difference between the different normative factors. Some of the hypotheses were accepted, while others were rejected. Moreover, it is believed that the results of the study will teach a logical viewpoint to the readers to value the importance of understanding the determinants affecting the online food delivery preference of customers.
\end{abstract}

Keywords: Buying Behavior; Online Food Couriers; Online Food Delivery Services; Online Food Delivery (OFD) Preference; Online Food Delivery Profile.

\section{INTRODUCTION}

The first food delivery service was for naengmyeon in Korea, recorded in 1768. Haejang-guk was also delivered for the yangban in the 1800s. Advertisement for food delivery and catering also appeared in the newspaper in 1906 (Kids.hankooki.com). Since then, this meal delivery service has been in demand and valuable. In the Philippines, the most commonly delivered meals are from fast-food chains like Jollibee, McDonald's, Shakey's, KFC, etc., and orders are being done through their delivery websites, mobile apps, or by phone.

Today, Covid 19 pandemic is said to be very contagious. People infected by it can be ill and can even be the cause of death. These are just some of the reasons why it is safer to stay indoors. Aside from the restrictions to dine in and take out, online food ordering is the new way of eating out. Hence, online food delivery courier services are growing more rapidly. Through online food delivery, the customers are safer from the threat of viruses and can buy easily through the online food delivery system.

Moreover, there are many online food delivery services to choose from. In Tuguegarao City, Cagayan alone, aside from fast-food chains, home-cooked meals like the famous panciterias in the city are available. Their food products can be delivered via several online food delivery couriers like Food Panda, Tok-Tok Rider, Ride Mommy, Teague - 2 Wheels, and Fast Food Delivery Service. Hence, people having diverse online food delivery preferences are now going to the web for information to patronize the exemplary food courier service for them. However, despite the demand of online food delivery service, it is still essential to understand the contributing factors towards OFD preference among the customers to complement customer needs with the inclination that drive them in their preference.

In this respect, the study aims to determine the online food delivery profile of the respondents and the degree of influence on the normative factors affecting their online food delivery (OFD) preference. Tests of relationships and differences among variables will also be conducted.

\section{STATEMENT OF THE PROBLEM}

The study aims to answer the following questions:

1. What is the online food delivery profile of the respondents in terms of: 
1.1 Type of Residence

1.2 Meal Preference

1.3 Food Industry Preference

1.4 Frequency of Patronizing Online Food Services Weekly

1.5 Amount Spent Weekly on Online Food Services

1.6 Mode of payment

2. What are the normative factors affecting online food delivery (OFD)

preference of respondents

2.1 Timeliness of Deliveries

2.2 Correctness of Orders Being Delivered

2.3 Condition of Orders Being Delivered

2.4 Quality of Customer Service

2.5 Navigation and Communication Skills of the Driver

3. What is the online food delivery courier preference of the respondents?

4. Is there a significant relationship between the normative factors affecting respondents' online food delivery preference and their online delivery profile?

5. Is there a significant relationship between the normative factors affecting respondents' online food delivery preference and their online food delivery courier preference?

6. Is there a significant difference among the normative factors affecting respondents' online food delivery food preference when grouped according to their preferred online food delivery courier?

\section{HYPOTHESES}

1. There is no significant relationship between the normative factors affecting respondents' online food delivery preference and their online food delivery profile.

2. There is no significant relationship between the normative factors affecting respondents' online food delivery preference and their online food delivery courier preference.

3. There is no significant difference in the degree of influence among the normative factors affecting respondents' online food delivery preference when grouped according to their preferred online food delivery courier.

\section{RESEARCH PARADIGM}

Online Food

Delivery Profile

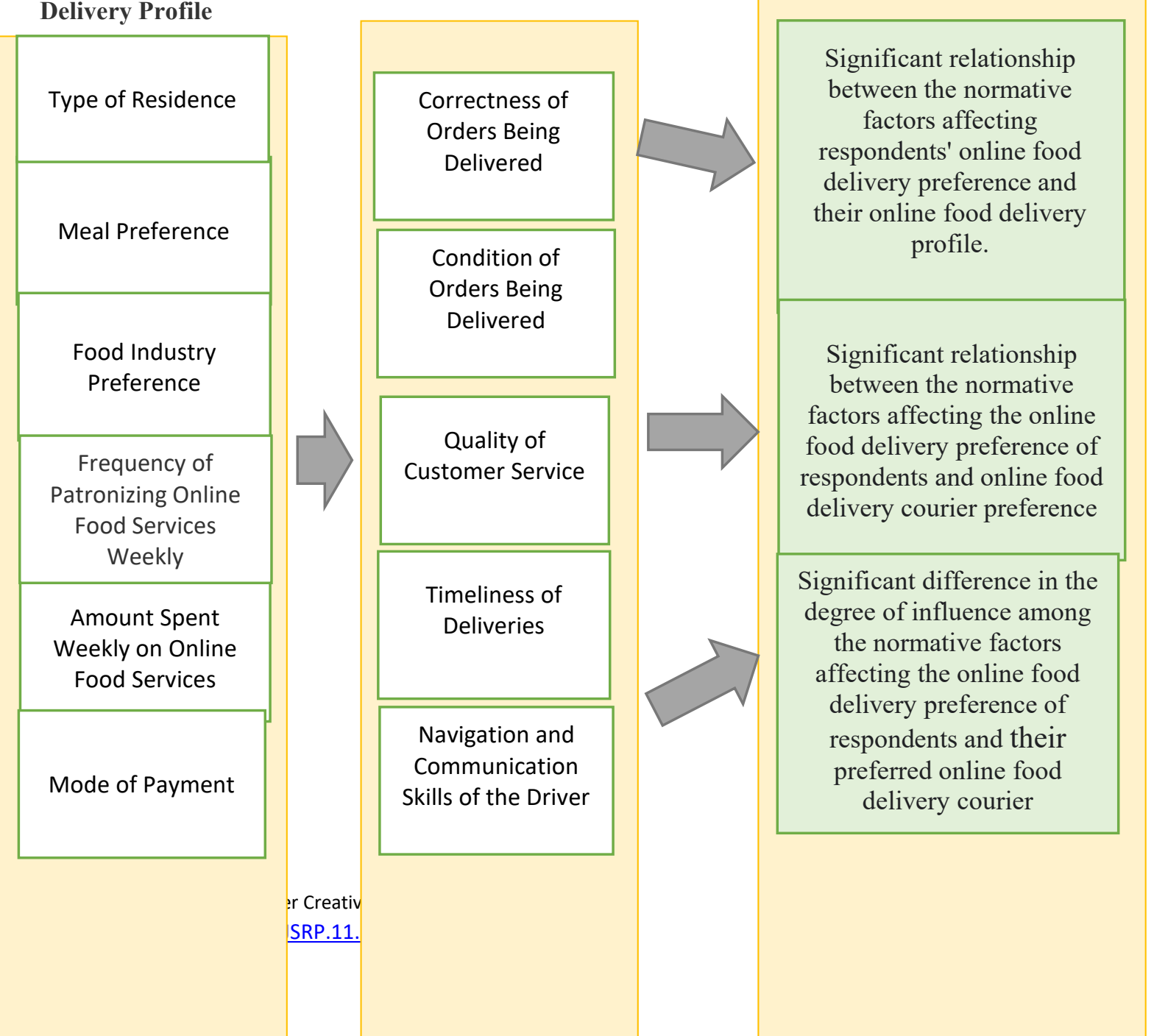

Normative Factors

Correctness of

orders Being

Delivered

Condition of

rders Being

Delivered

Customer Service 
The figure shows the respondents' six online food delivery profiles and the five normative factors affecting their online food delivery preference. The lines of the profile variables and normative factors are connected to the null hypotheses to test whether the three (3) null hypotheses in the study will be accepted or rejected through the survey questionnaire to be answered by the participants that will be treated and interpreted.

\section{SIGNIFICANCE OF THE STUDY}

The results of the study will be helpful to the following individuals:

Business Subject Professors: The study can enhance the conceptual understanding of professors in the field of business that needs to be incorporated in a business class.

Customers: The result of the study will aid customers in coming up with a rational decision in choosing the exemplary food courier service to patronize.

Food Industry Owners: Principles and concepts used in the study will serve as a basis for food industry owners to understand customers ' food delivery preferences that will allow them to plan and apply better marketing strategies.

Food Courier Service: The normative factors affecting customers' online food delivery preference can be the key ingredient in enabling the business to generate a constant revenue stream and not lag behind competitors.

Students: The emphasis of the study is placed on the concepts of the factors affecting the online food delivery preference of consumers and their online food delivery profile, which can be beneficial to CBEA students who will soon be employed in the business world.

Future Researchers: The study would guide parallel studies to be conducted using a broader scope.

\section{SCOPE AND DELIMITATION}

The study is delimited in determining the online food delivery profile of the respondents and the degree of influence on the normative factors affecting their online food delivery (OFD) preference. Tests of relationships and differences among variables were also conducted. A questionnaire via google form was administered to all the BSBA major in Marketing Management students of Cagayan State University, Andrews Campus for $1^{\text {st }}$ semester, A.Y. 2021-2022.

\section{DEFINITION OF TERMS}

The following terms are subsequently defined for easier understanding by the readers:

Buying Behavior: The decision process made by the customers in choosing the online food delivery and online food courier to buy and deliver the food products they need and want.

Online Food Courier Service: Refers to Food Panda, Tok-Tok Rider, Ride Mommy, Teague - 2 Wheels food delivery services in Tuguegarao City.

Online Food Delivery (OFD) Preference: This refers to the various factors like Timeliness of Deliveries, Correctness of Orders Being Delivered, Condition of Orders Being Delivered, Quality of Customer Service, Navigation and Communication Skills of the Driver

Online Food Delivery Profile: It refers to the type of residence, meal preference, food industry preference, the amount spent weekly on online food services, and mode of payment of the respondents.

Online Food Delivery Preference: The food industry where the customers acquire the food products based on the various normative factors.

\section{RESEARCH METHODOLOGY}

\section{RESEARCH DESIGN}

The method employed is the descriptive correlational method since the primary purpose of the study is to determine the online food delivery profile of the respondents and its relationship to the normative factors affecting their online food delivery (OFD) preference. 
According to Sevilla, a descriptive study involves collecting data to test hypotheses or answer questions concerning the current status or subject of the study. It also determines and reports the way things are, and correlational studies are designed to help the researchers determine the extent to which different variables are related to each other in the population of interest.

\section{RESPONDENTS OF THE STUDY}

The researchers considered the whole population of BSBA major in Marketing Management from $1^{\text {st }}$ year to $4^{\text {th }}$ year of Cagayan State University, Andrews Campus for $1^{\text {st }}$ semester, A.Y. 2021-2022 to be the study's respondents.

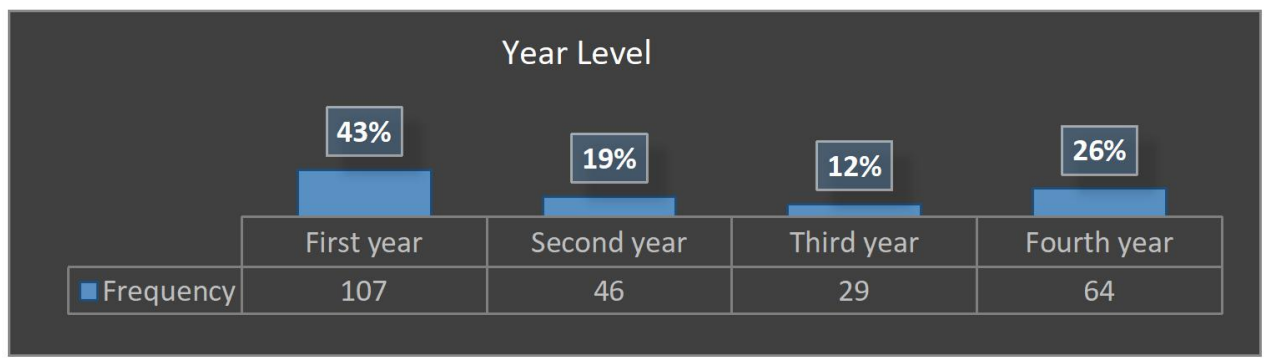

Table 1 presents the frequency and percentage distribution of the respondents per year level. From the 286 total population of BSBA major in Marketing Management students, 246 students responded to the survey, broken as follows: 107 or $43 \%$ from $1^{\text {st }}$ year, 46 or $19 \%$ from $2^{\text {nd }}$ year, 29 or $12 \%$ from $3^{\text {rd }}$ year, and 64 or $26 \%$ from $4^{\text {th }}$ year respectively.

\section{DATA GATHERING INSTRUMENT}

This study utilized the use of a survey questionnaire as the primary source of data. Part 1 was centered on the online food delivery profile of the respondents, like the type of residence, meal preference, food industry preference, the amount spent weekly on online food services, and mode of payment. Part 2 consists of the normative factors affecting the online food delivery preference of the respondents, such as timeliness of deliveries, the correctness of orders being delivered, condition of orders being delivered, quality of customer service, and navigation and communication skills of the driver. Part 3 consists of the online food courier service preference of the respondents.

\section{DATA GATHERING PROCEDURE}

The researcher of the study followed the following procedures to determine the online food delivery profile of the respondents and the degree of influence on the normative factors affecting their online food delivery (OFD) preference. First, the researcher presented the research proposal to the college. After which, the researcher constructed a questionnaire consisting of three (3) parts. Next to that, the researcher asked permission from the College Dean through the college research coordinator to float the questionnaire to the respondents via google form. After the data had been collected, it was statistically treated, analyzed, and interpreted.

\section{STATISTICAL TREATMENT AND ANALYSIS}

The study used the following statistical tools needed in the analysis of the data.

Frequency count and the percentage were used to categorize the online food delivery profile of respondents. For the degree of influence among the normative factors affecting the online food delivery preference of customers, the Likert Scale Value was assigned to score the five categories, and the weighted mean was used to analyze the results. Moreover, a descriptive scale was applied by the researcher for the assessment of the results (4 - Very High Influence, 3 - High Influence, 2 - Low Influence, 1 - No Influence). Furthermore, to determine the significant relationship of the normative factors affecting customers' online food delivery preference and online delivery profile, the Chi-Square test, and One-Way ANOVA were used to test the significant difference in the degree of influence among the normative factors affecting the online food delivery preference of customers. 


\title{
RESULTS AND DISCUSSION
}

\section{Table 2}

Online Food Delivery Profile of Respondents in Terms of

\author{
Type of Residence
}

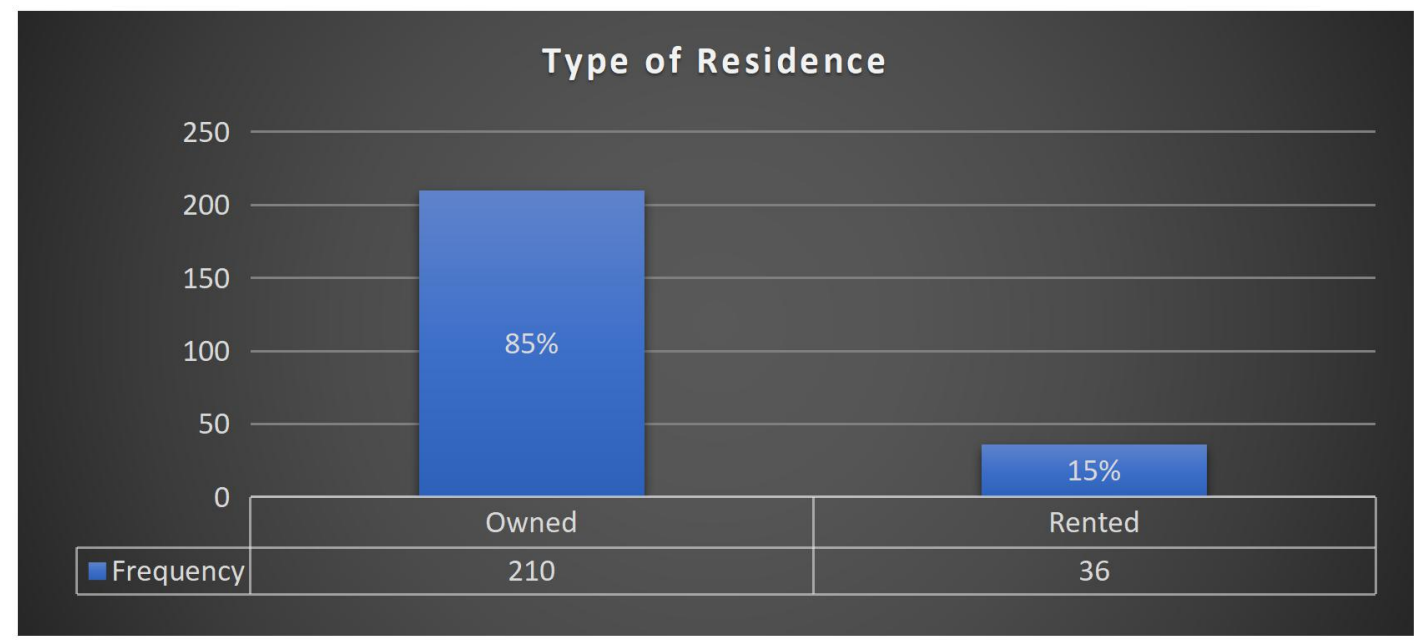

Table 2 presents the frequency and percentage distribution of respondents in terms of the type of residence. As shown in the above data, 210 or $85 \%$ of the respondents owned their homes. It is a fact that a significant percentage of the respondents' population is from outside the city, and they only stay in Tuguegarao during face-to-face classes. However, because of the pandemic, respondents are staying in a residence they owned. Most of the time, houses in rural areas are owned and not rented. On the other hand, 36 or $15 \%$ of the respondents are renting because they are not the residence of the place, and some respondents do not have the means to own a house.

Table 3

Online Food Delivery Profile of Respondents in Terms of

Meal Preference to Order Online

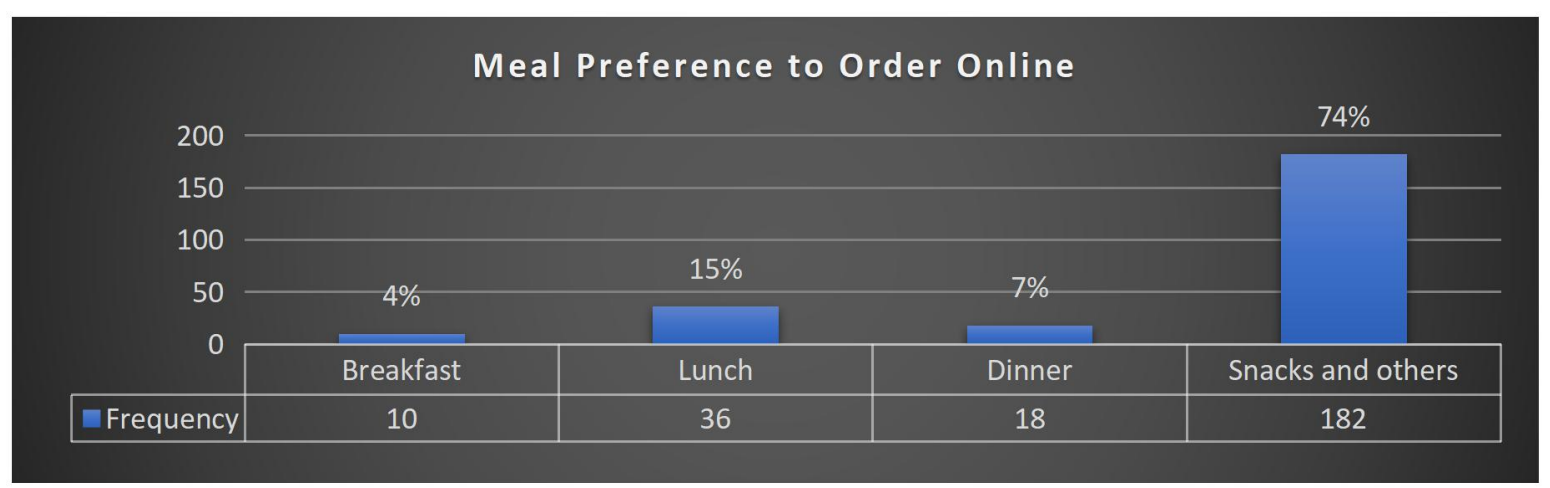

Table 3 presents respondents' frequency and percentage distribution regarding the type of meal preference to order online. 182 or $74 \%$ of the respondents prefer to order snacks and others online. This is a manifestation that aside from the three regular meals (breakfast, lunch, and dinner), the respondents still order snacks and others online to satisfy their cravings for food, a reason why they consider themselves food lovers. However, only 10 or $4 \%$ of the respondents order breakfast online because of the limited number of food delivery couriers during early breakfast. 
Table 4

Online Food Delivery Profile of Respondents in Terms of

Food Industry Preference

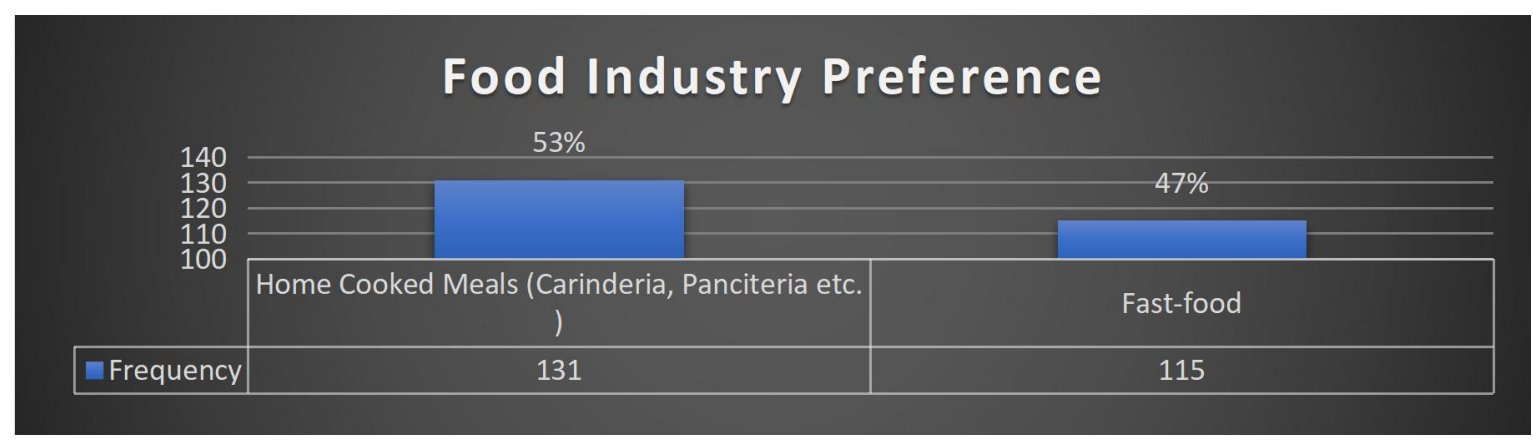

Table 4 presents the frequency and percentage distribution of respondents in terms of food industry preference. The data reveals that 131 or $53 \%$ of the respondents prefer to order food from home-cooked meals (carinderia, panciteria, etc.). They choose the cheaper option because they are tight when it comes to budgeting their expenses, especially this pandemic. However, 115 or $47 \%$ of the respondents can't just say no to the food offerings of fast-food chains.

Table 5

Online Food Delivery Profile of Respondents in Terms of Frequency of Patronizing Online Food Services Weekly

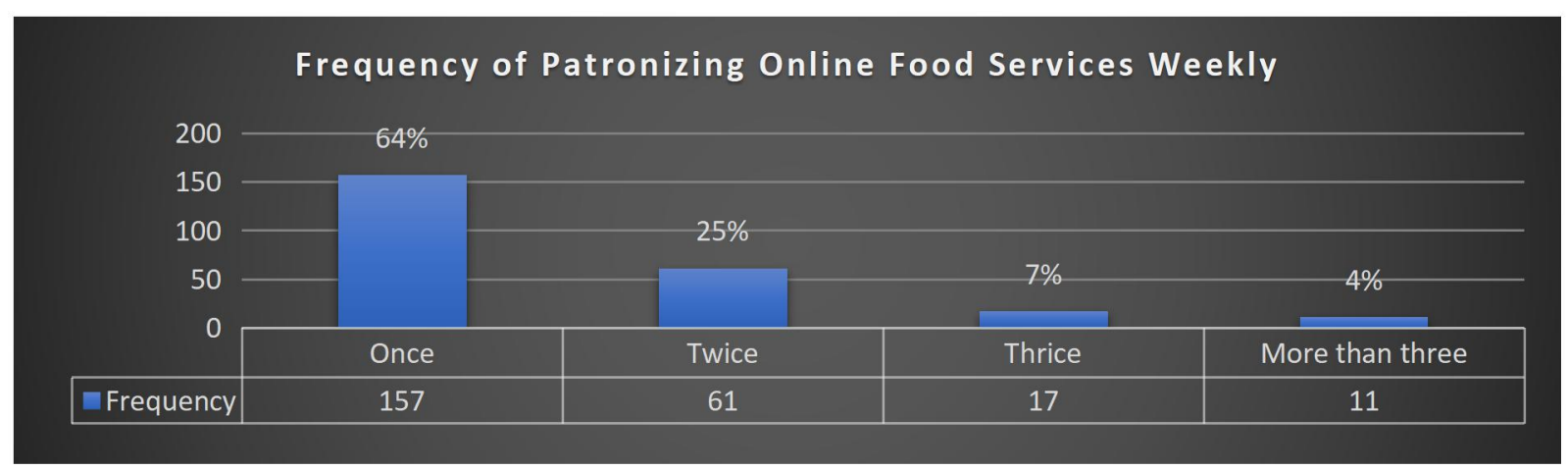

Table 5 presents the frequency and percentage distribution of respondents regarding the frequency of patronizing online food services weekly. The table shows that 157 or $64 \%$ of the respondents patronize online food services once every week, and only 11 or $4 \%$ patronize online food services weekly. This proves that most of the respondents are financially challenged and are not capable of buying food online. They just eat the meal they cook and prepare at home. 
Table 6

Online Food Delivery Profile of Respondents in Terms of Amount Spent Weekly on Online Food Services

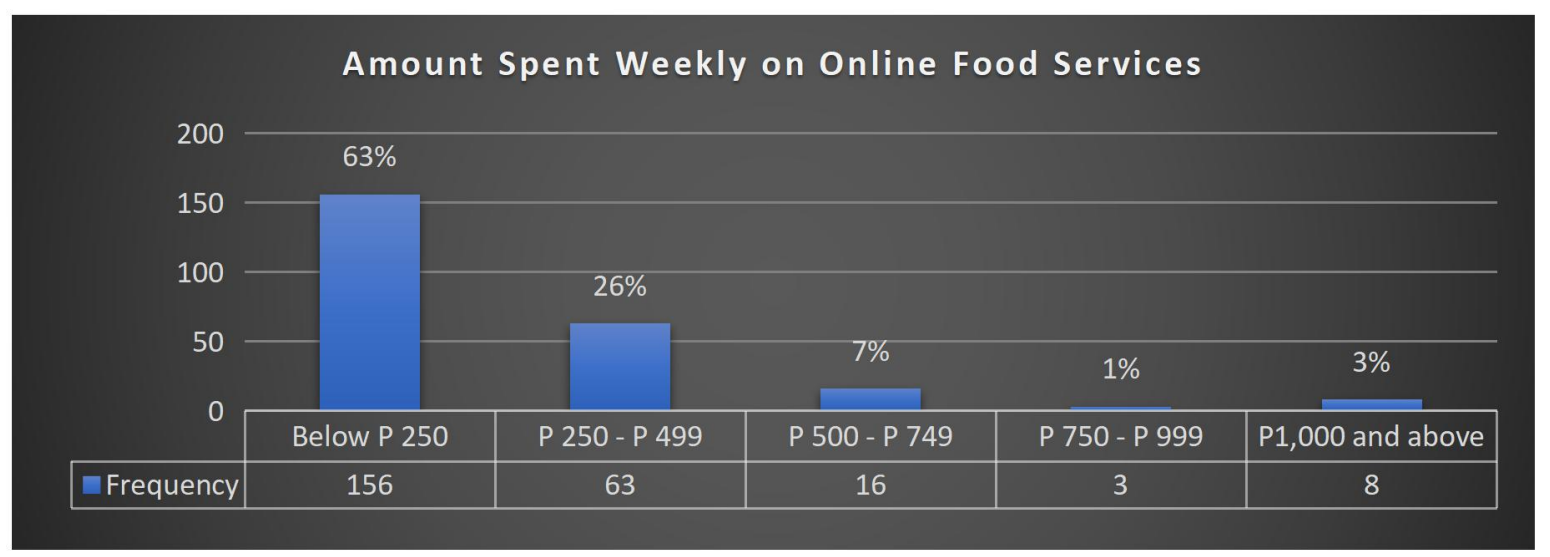

Table 6 presents respondents' frequency and percentage distribution regarding the amount spent weekly on online food services. As shown in the above table, 156 or $63 \%$ of the respondents spend below P250, and 3 or 1\% spend P750-P900. Since the respondents are students, they only depend on their parents or guardians' allowance/s or financial support. Thus, they need to allocate their finances wisely.

Table 7

Online Food Delivery Profile of Respondents in Terms of Mode of Payment

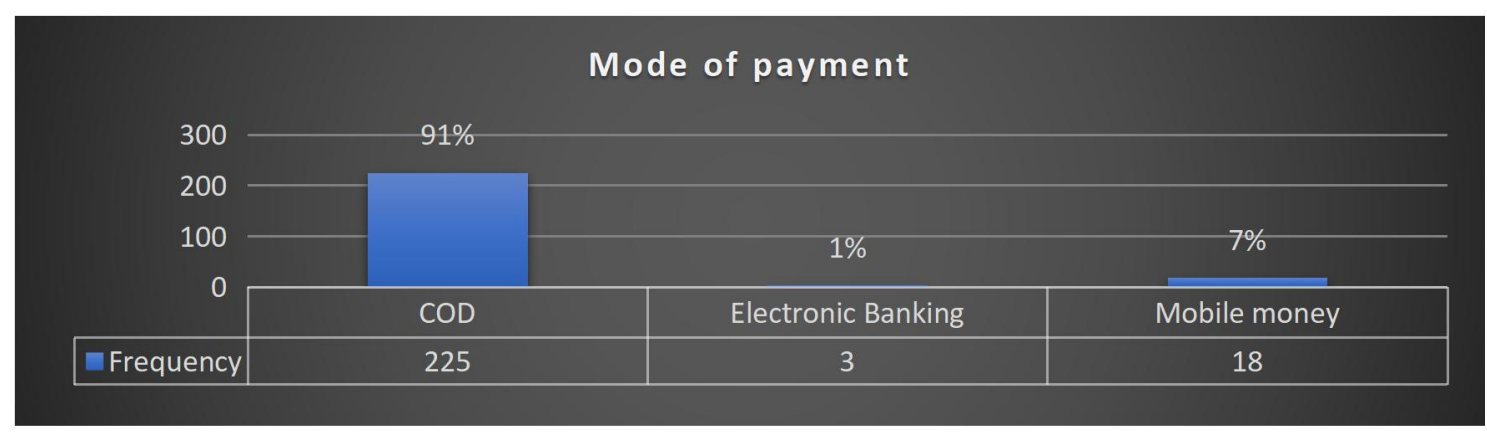

Table 7 presents the frequency and percentage distribution of respondents in terms of mode of payment. From the various source of the mode of payment, 225 or $91 \%$ of the respondents prefer COD, and only 3 or $1 \%$ pay through electronic banking. This explains that as BSBA Marketing students, they are familiar with various scams and skims of illegitimate sellers, hence to have a sigh of relief, they prefer Cash on Delivery. After all, not all of the respondents have a bank account. 
Table 8

Normative Factors Affecting the

Online Food Delivery Preference of Respondents

\begin{tabular}{|l|c|c|}
\hline $\begin{array}{l}\text { Normative factors affecting the online food delivery (OFD) preference of } \\
\text { customers }\end{array}$ & $\begin{array}{c}\text { Weighted } \\
\text { mean }\end{array}$ & Interpretation \\
\hline Timeliness of Deliveries - Prompt service and delivery time & 3.22 & High Influence \\
\hline Correctness of Orders Being Delivered - Accuracy of orders being delivered & 3.45 & $\begin{array}{c}\text { Very High } \\
\text { Influence }\end{array}$ \\
\hline $\begin{array}{l}\text { Condition of Orders Being Delivered - The orders being delivered are fresh, } \\
\text { well-cooked, and well-presented }\end{array}$ & 3.43 & $\begin{array}{c}\text { Very High } \\
\text { Influence }\end{array}$ \\
\hline $\begin{array}{l}\text { Quality of Customer Service - An online food delivery service that is service- } \\
\text { oriented; treats customers with respect and care. }\end{array}$ & 3.53 & $\begin{array}{c}\text { Very High } \\
\text { Influence }\end{array}$ \\
\hline $\begin{array}{l}\text { Navigation and Communication Skills of the Driver - A driver who } \\
\text { communicates effectively and is aware of routes to ensure timely delivery }\end{array}$ & 3.44 & $\begin{array}{c}\text { Very High } \\
\text { Influence }\end{array}$ \\
\hline
\end{tabular}

Table 8 shows the normative factors affecting the online food delivery preference of customers. The table shows that only the factor on "timeliness of deliveries" has a weighted mean of 3.22 or high influence. Although the timeliness of delivery is essential when ordering food online to enjoy hot and fresh food. The respondents understand the dilemmas of online food delivery stores and online food courier services in complying with the minimum health protocols like restricted number of workforce in the establishment, number of working hours, and the limited number of online food couriers.

The "correctness of orders being delivered" has a weighted mean of 3.45 or very high influence. This explains that it's but regular for customers to want precisely what they ordered. When customers receive incorrect food order/s, they will be disappointed and may look for another online delivery service or online food courier that will not require them to spend much time and effort to make it right.

Moreover, when it comes to the "condition of orders being delivered." As revealed in the data, this factor has a weighted mean of 3.43 or very high influence. Since this factor is significant to the customers, online food couriers must be responsible enough to ensure that the food is of good "quality" or condition when it reaches the customers.

In terms of "quality of customer service." This factor has a weighted mean of 3.53 or very high influence. This implies that it is vital for online food services to have courteous staff and have practical communication skills. These attributes will make the customers feel valued.

Lastly, the "navigation and communication skills of the driver" factor have a weighted mean of 3.44 or very high influence. Since timeliness of delivery is essential to the respondents, it is necessary for drivers of online food services to possess good navigation and communication skills to timely deliver the food in the correct location.

Table 9

Preferred Online Food Delivery Courier of Respondents

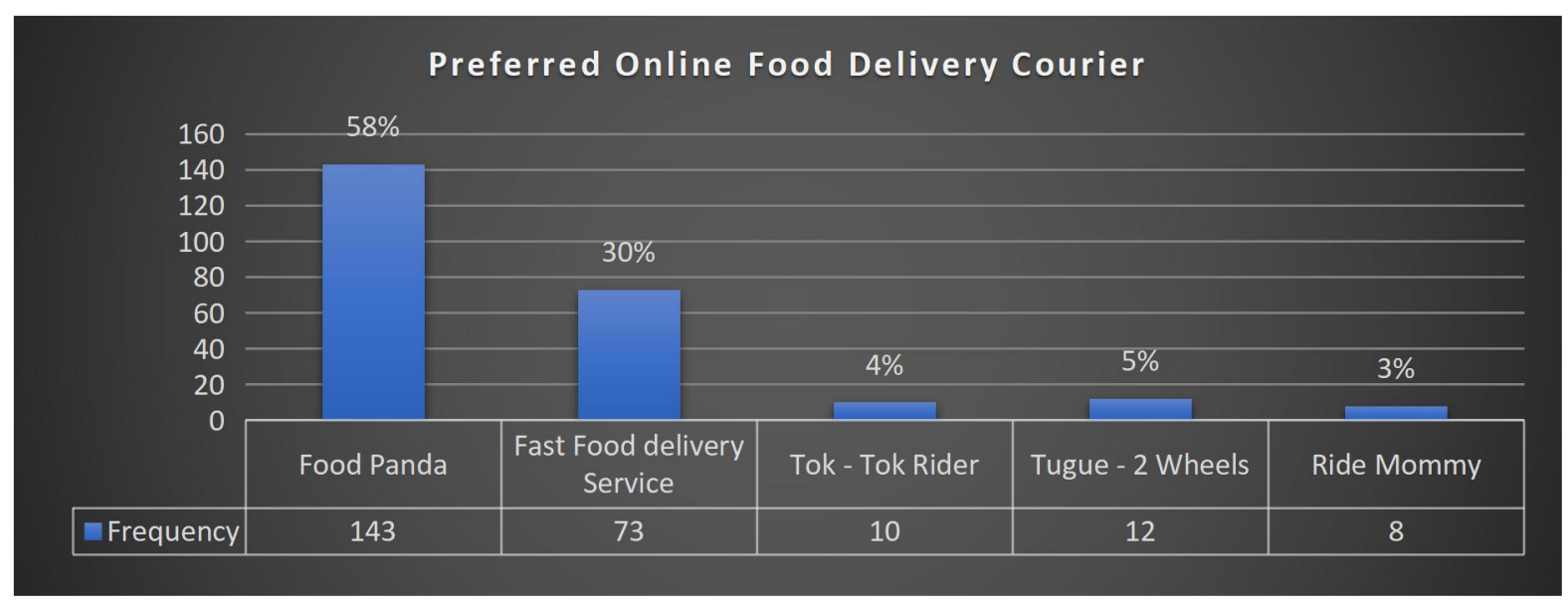


Table 9 shows the preferred food delivery courier of customers. As shown on the table, the respondents' most selected online food delivery courier is food panda, with a frequency of 143 or 58\%. This can be attributed to various factors such as popularity, number of available riders, user-friendly mobile application, their connections with online food delivery services, and different mode of payment options. On the other hand, the least preferred online food delivery courier is the Ride Mommy, with 8 or $3 \%$ frequency. This is because ride mommy is the newest online food delivery in the local market; hence customers are not very familiar with it.

\section{Table 10}

Relationship Between the Normative Factors Affecting the Online Food Delivery Preference of Respondents and their Online Food Delivery Profile

\begin{tabular}{|c|c|c|c|c|c|c|}
\hline \multirow[b]{2}{*}{$\begin{array}{l}\text { Normative factors affecting the online food delivery (OFD) } \\
\text { preference of costumers }\end{array}$} & \multicolumn{6}{|c|}{ Chi Square/Likelihood ratio } \\
\hline & $\begin{array}{c}\text { Type of } \\
\text { Residence }\end{array}$ & \begin{tabular}{|c|} 
Meal \\
Preference to \\
Order \\
Online
\end{tabular} & $\begin{array}{l}\text { Food } \\
\text { Industry } \\
\text { Preference }\end{array}$ & $\begin{array}{l}\text { Frequency of } \\
\text { Patronizing Online } \\
\text { Food services Weekly }\end{array}$ & $\begin{array}{c}\text { Amount Spent } \\
\text { Weekly on Online } \\
\text { Food Services }\end{array}$ & $\begin{array}{l}\text { Mode of } \\
\text { payment }\end{array}$ \\
\hline Timeliness of Deliveries - Prompt service and delivery time & 0.889 & 0.475 & 0.026 & 0.340 & 0.408 & 0.082 \\
\hline $\begin{array}{l}\text { Correctness of Orders Being Delivered - Accuracy of orders } \\
\text { being delivered }\end{array}$ & 0.031 & 0.501 & 0.290 & 0.468 & 0.658 & 0.222 \\
\hline $\begin{array}{l}\text { Condition of Orders Being Delivered - The orders being } \\
\text { delivered are fresh, well-cooked and well-presented }\end{array}$ & 0.310 & 0.071 & 0.103 & 0.795 & 0.700 & 0.333 \\
\hline $\begin{array}{l}\text { Quality of Customer Service - An online food delivery service } \\
\text { that is service oriented; treats costumers with respect and care. }\end{array}$ & 0.562 & 0.433 & 0.001 & 0.823 & 0.206 & 0.490 \\
\hline $\begin{array}{l}\text { Navigation and Communication Skills of the Driver - A driver } \\
\text { who communicates effectively and is aware of routes to ensure } \\
\text { timely delivery }\end{array}$ & 0.808 & 0.191 & 0.163 & 0.414 & 0.292 & 0.165 \\
\hline
\end{tabular}

Table 10 presents the relationship between the normative factors affecting respondents' online food delivery preference and their online food delivery profile. As shown on the table, the element along "Correctness of Orders Being Delivered" has a significant relationship to the online delivery profile of respondents in terms of residence. The meal preference to order online of most of the respondents are snacks and others. Since they stay in their place, they cook their breakfast, lunch, and dinner at home. Therefore, the accuracy of these food orders delivered can be an ultimate guide that online food delivery services must consider regarding the respondent's residence. The food industry preference of respondents likewise has a significant relationship to the "Timeliness of Deliveries" and "Quality of Customer Service" factors affecting customers' online food delivery preference. It is ordinary for respondents to prefer online food delivery services that offer prompt service and delivery time. Since this factor is usually correlated to the quality of food to be delivered, the saying "the earlier, the better" to enjoy hot and fresh food must be considered. "Quality of Customer Service," on the other hand, is also correlated to the food industry preference of respondents. This implies that service quality plays a crucial role in the operations of online food services. Aside from the quality of food, the quality of customer service has a significant impact on the satisfaction and loyalty of the respondents to the food industry. Other online delivery profiles like "meal preference to order online;" "frequency of patronizing online food services weekly;" "the amount spent weekly on online food services;" and "mode of payment" has no significant relationship to the normative factors affecting the online food delivery (OFD) preference of customers.

Table 11

Relationship Between the Normative Factors Affecting the Online Food Delivery Preference of Respondents and their Online Food Courier Service Preference

\begin{tabular}{|l|c|}
\hline $\begin{array}{c}\text { Normative factors affecting the online food delivery (OFD) } \\
\text { preference of costumers }\end{array}$ & $\begin{array}{c}\text { Chi Square/Likelihood ratio } \\
\text { Preferred Online Food Delivery }\end{array}$ \\
\hline $\begin{array}{l}\text { Timeliness of Deliveries - Prompt service and delivery time } \\
\text { being delivered }\end{array}$ & 0.609 \\
\hline $\begin{array}{l}\text { Condition of Orders Being Delivered - The orders being } \\
\text { delivered are fresh, well-cooked and well-presented }\end{array}$ & 0.110 \\
\hline $\begin{array}{l}\text { Quality of Customer Service - An online food delivery service } \\
\text { that is service oriented; treats costumers with respect and care. }\end{array}$ & 0.126 \\
\hline $\begin{array}{l}\text { Navigation and Communication Skills of the Driver - A driver } \\
\text { who communicates effectively and is aware of routes to ensure } \\
\text { timely delivery }\end{array}$ & 0.565 \\
\hline
\end{tabular}


Table 11 presents the relationship between the normative factors affecting respondents' online food delivery preference and online food courier service preference. As reflected in the above table, all five (5) factors do not significantly relate to online food courier service preference. This means that the respondents' online food courier service preference is not affected by the normative factors affecting their online food delivery preference.

Table 12

The difference on the Normative Factors Affecting the Online Food Delivery Preference of Respondents and their Online Food Delivery Courier Preference

\begin{tabular}{|l|c|c|c|}
\hline \multicolumn{1}{|c|}{$\begin{array}{c}\text { Normative factors affecting the online food delivery (OFD) } \\
\text { preference of costumers }\end{array}$} & \multicolumn{2}{|c|}{ Preferred Online Food Delivery Courier } \\
\cline { 2 - 4 } & F- ratio & Sig. & Interpretation (@=0.05) \\
\hline Timeliness of Deliveries - Prompt service and delivery time & 0.154 & 0.927 & Accept Null Hypothesis \\
\hline $\begin{array}{l}\text { Correctness of Orders Being Delivered - Accuracy of orders } \\
\text { being delivered }\end{array}$ & 1.275 & 0.283 & Accept Null Hypothesis \\
\hline $\begin{array}{l}\text { Condition of Orders Being Delivered - The orders being } \\
\text { delivered are fresh, well-cooked and well-presented }\end{array}$ & 4.218 & 0.006 & Reject Null Hypothesis \\
\hline $\begin{array}{l}\text { Quality of Customer Service - An online food delivery service } \\
\text { that is service oriented; treats costumers with respect and care. }\end{array}$ & 0.98 & 0.403 & Accept Null Hypothesis \\
\hline $\begin{array}{l}\text { Navigation and Communication Skills of the Driver - A driver } \\
\text { who communicates effectively and is aware of routes to ensure } \\
\text { timely delivery }\end{array}$ & 1.419 & 0.238 & Accept Null Hypothesis \\
\hline
\end{tabular}

Table 12 presents the difference between respondents' online food delivery preference and their online food delivery courier preference. As reflected in the above table, most of the normative factors affecting the online food delivery preference of the respondents have no significant difference to their preferred online delivery courier because the significant level computed is above the alpha level of significance which is 0.05 . In contrast, only the normative factor "Condition of Orders Being Delivered" significantly differs from respondents' online food delivery courier preference. This implies that the condition of food orders to be delivered to them in terms of their freshness and presentation is a factor the respondents consider in choosing their food delivery courier.

\section{SUMMARY, CONCLUSIONS, AND RECOMMENDATION}

This chapter presents the summary, conclusions, and recommendations based on the results of the study.

\section{SUMMARY OF FINDINGS:}

\section{Online Food Delivery Profile of Respondents}

Along with Type of Residence, 210 or $85 \%$ of the respondents owned their residence, and 36 or $15 \%$ rented. Regarding Meal Preference to Order Online, 182 or $74 \%$ of the respondents prefer ordering snacks and others online, and only 10 or $4 \%$ prefer ordering breakfast online. Moreover, under Food Industry Preference, 131 or 53\% of the respondents prefer to order food from a home-cooked meal like carinderia and panciteria. However, 115 or $47 \%$ of the respondents order food from fast-food chains like Jollibee, McDonald's, Chowking, etc. Regarding Frequency of Patronizing Online Food Services Weekly, 157 or $64 \%$ of the respondents patronize online food services weekly, and only 11 or $4 \%$ patronize online food services weekly. On the other hand, 156 or $63 \%$ of the respondents spend below P250, and 3 or 1\% of them spend P750-900 along with the online food delivery profile of Amount Spent Weekly on Online Food Services. Lastly, under Mode of Payment, 225 or 91\% of the respondents prefer COD, and only 3 or $1 \%$ choose electronic banking.

\section{Factors Affecting the Online Food Delivery Preference of Respondents}

Only the factor "Timeliness of Deliveries" has a weighted mean of 3.22 or high influence. In contrast, the following four (4) other factors have a descriptive value of very highly influence: "Correctness of Orders Being Delivered" has a weighted mean of 3.45; "Condition of Orders Being Delivered" is 3.43; "Quality of Customer Service" is 3.53 and "Navigation, and Communication Skills of the Driver" has a weighted mean of 3.44 respectively.

\section{Preferred Online Food Delivery Courier of Respondents}

Of the five (5) preferred online food delivery couriers, 143 or 58\% favor Food Panda, and 8 or 3\% favor Ride Mommy.

\section{Relationship Between the Normative Factors Affecting the Online Food Delivery Preference of Respondents and their Online Delivery Profile}


The factor along "Correctness of Orders Being Delivered" has a significant relationship to the online delivery profile of respondents in terms of residence. The food industry preference is likewise has a significant relationship to the "Timeliness of Deliveries" and "Quality of Customer Service" factors affecting the online food delivery preference of customers. "Quality of Customer Service," on the other hand, is also correlated to the food industry preference of respondents. Other online delivery profiles like "meal preference to order online;" "frequency of patronizing online food services weekly;" "the amount spent weekly on online food services;" and "mode of payment" has no significant relationship to the normative factors affecting the online food delivery (OFD) preference of customers.

\section{Relationship Between the Normative Factors Affecting the Online Food Delivery Preference of Respondents and their Online Food Delivery Courier Preference}

All five (5) normative factors do not significantly correlate to respondents' online food courier service preference.

\section{The difference on the Normative Factors Affecting the Online Food Delivery Preference of Respondents and their Online Food Delivery Courier Preference}

Most of the normative factors affecting the online food delivery preference of the respondents have no significant difference from their preferred online delivery courier. In contrast, only the normative factor "condition of orders being delivered" significantly differs from respondents' online food delivery courier preference.

\section{CONCLUSIONS:}

\section{Online Food Delivery Profile of Respondents}

In terms of Type of Residence, most of the respondents' residences are owned. The respondents stay in their houses owned by their families because of the pandemic, and only a few of them are renting because of financial constraints. For the Meal Preference to Order Online, the respondents usually buy online snacks and others to satisfy their cravings for food offered by home-cooked meals like carinderia and panciteria, etc. same with the food offerings of fast-food chains. Moreover, the Food Industry Preference of most of the respondents is the home-cooked meals, and some of them prefer the food of fast-food chains; this can be attributed to the purchasing power of the respondents. Hence, they choose the cheaper option. For the Frequency of Patronizing Online Food Services Weekly, the study reveals that almost all respondents only buy once a week, and very few buy more than thrice a week. This has something to do with the purchasing power of the respondents, they are considered financially challenged, and since they are still students, they are only dependent on the financial support of their parents or guardians. Therefore, 63\% of the respondents spend below P250 for the online profile Amount Spent Weekly on Online Food Industry Services. Lastly, it can also be inferred that the respondents are rational buyers because of their awareness of various scams and skims in online buying. Hence, they prefer COD for the Mode of Payment.

\section{Factors Affecting the Online Food Delivery Preference of Respondents}

From the five (5) normative factors affecting respondents' online food delivery preference, only the "Timeliness of Deliveries" factor highly influences their online food delivery preference. Although the timeliness of delivery is of utmost importance when ordering food online. The four other factors are more critical as perceived by the respondents. As much as they want the food to be delivered quickly at their doorstep, they understand the dilemmas online food delivery stores and food couriers are experiencing when it comes to prompt service and delivery because of the pandemic. Regarding "Correctness of Orders Being Delivered," this factor has a very high influence on respondents' online food delivery preference, same with the other factors. The correctness of food orders being delivered is critical in choosing the online food delivery to patronize. Without this aspect, customers will look for another store that will satisfy them concerning the accuracy of food orders being delivered. In like manner, about the factor "Condition of Orders Being Delivered," it is crucial for the online food delivery services to consider ways to deliver quality food products that can make the customers happy. "Quality of Customer Service" has a very-highly influence on the respondents because more than the quality of food they order online, the quality of customer service they receive is of utmost importance when ordering food online. This will allow them to enjoy the customer experience. Last but not the least is the "Navigation and Communication Skills of the Driver" factor. Since the respondents' timeliness of delivery is essential, drivers must possess navigation and communication skills to deliver the food quickly and in the right direction.

\section{Preferred Online Food Delivery Courier}

Many factors may contribute to customers' online food delivery courier preference, such as popularity, number of available riders, user-friendly mobile applications, connections with online food delivery services, and various modes of payment options. In the case of the 246 respondents, 143 of them prefer Food Panda, and 73 favor fast food delivery service over other online food delivery couriers like Tok-Tok Rider, Teague-2Wheels, and Ride Mommy.

\section{Relationship Between the Normative Factors Affecting the Online Food Delivery Preference of Respondents and their Online Delivery Profile}

"Correctness of Orders Being Delivered" has a significant relationship to the online delivery profile of respondents in terms of residence. The respondents stay in their homes; hence they cook and prepare their meals for breakfast, lunch, and dinner. However, most of them order snacks and others online to save time on meal preparation and enjoy it. Hence, the online food delivery services must take the accuracy of food delivered to them regarding the respondent's residence. The food industry 
preference is likewise correlated to "Timeliness of Deliveries" and "Quality of Customer Service." This proves that prompt service and delivery time is essential to enjoy hot and fresh food.

On the other hand, "Quality of Customer Service" is also correlated to the food industry preference of respondents. This is a manifestation that aside from food, the quality of customer service has a significant impact on the satisfaction and loyalty of the respondents to the food industry. Other online delivery profiles like "meal preference to order online;" "frequency of patronizing online food services weekly;" "the amount spent weekly on online food services;" and "mode of payment" have no significant relationship to the normative factors affecting the online food delivery (OFD) preference of customers.

\section{Relationship Between the Normative Factors Affecting the Online Food}

Delivery Preference of Respondents and their Online Food Delivery Courier Preference

All five (5) normative factors do not significantly correlate to respondents' online food courier service preference. This means that the respondents' online food courier service preference is not affected by the normative factors affecting their online food delivery preference.

\section{The difference on the Normative Factors Affecting the Online Food Delivery Preference of Respondents and their Online Food Delivery Courier Preference}

Most of the normative factors affecting the online food delivery preference of the respondents have no significant difference from their preferred online delivery courier. In contrast, only the normative factor "Condition of Orders Being Delivered" significantly differs from respondents' online food delivery courier preference. This implies that the condition of food orders to be delivered to them in terms of their freshness and presentation is a factor the respondents consider in choosing their delivery courier.

\section{RECOMMENDATIONS:}

Based on the above conclusions, the researcher highly recommends the following:

The study results should be a basis for the store owners to improve their services, particularly in the areas revealed by the study that significantly affect customer preference.

Online food delivery services should offer a variety of food options on their menu. They also need to train their staff since there is a big difference in the quality of service rendered by trained staff compared to a team with little or no training.

The results can also be used to craft policies and procedures that the food industry owners can adopt to have a certain standard in providing food delivery services.

Online food delivery couriers must not be limited to Tuguegarao alone; they may offer delivery services outside the city to capture a bigger market.

Customers should check on reviews available on various internet sites to help them get a good "sense" of the food's appearance, taste and feedback from customers. This will help them decide whether the food delivery service is what they want.

Similar studies can be conducted covering a more comprehensive range of respondents to understand better the factors influencing customers' online food delivery preferences. Furthermore, more detailed research on the normative factors affecting customers' online food delivery preference can also be studied, like considering additional factors or criteria in evaluating these factors.

A study on customer satisfaction in relation to these normative factors affecting the online food delivery preference and their preferred online food delivery couriers can also be conducted.

\section{REFERENCES:}

1. Cumagun, Joseph, et al. (2015) Profile Variables and the Degree of Influence of the Normative Factors Affecting the Buying Behavior of CBEA Students. International Journal of Advanced Research in Management and Sciences

2. https://www.healthline.com/nutrition/ultimate-guide-to-choosing-a-meal-delivery-service-12-factors-to-consider

3. https://reqtest.com/testing-blog/guide-deliver-quality-product-satisfy-customers/

4. https://www.zendesk.com/blog/good-customer-service-defined/ 
5. Lan, H., Ya'nan, L. I., \& Shuhua, W. (2016). Improvement of online food delivery service based on consumers' negative comments. Canadian Social Science, 12(5), 84-88.

6. Lee, J. H., Lee, E. H., \& Choe, E. (2014). Study on eating habits and food preference for breakfast of elementary, middle, or high school students in the Incheon area. Korean journal of food and cookery science, 30(2), 170-182.

7. Lee, E. Y., Lee, S. B., \& Jeon, Y. J. J. (2017). Factors influencing the behavioral intention to use food delivery apps. Social Behavior and Personality: an international journal, 45(9), 1461-1473.

8. Liu, W.; Batra, R.; Wang, H. (2017) Product touch and consumers' online and offline buying: The role of mental representation. J. Retail. 2017, 93, 369-381.

9. Saad, Ahmed Tausif (2020). Factors Affecting Online Food Delivery Service in Bangladesh: An Empirical Study. Research Gate.

10. Suhartanto, D., Helmi Ali, M., Tan, K. H., Sjahroeddin, F., \& Kusdibyo, L. (2019). Loyalty toward online food delivery service: the role of e-service quality and food quality. Journal of foodservice business research, 22(1), 81-97.

11. Suk Won Lee 1, Hye Jin Sung 2 \& Hyeon Mo Jeon 1. (2019) Determinants of Continuous Intention on Food Delivery Apps: Extending UTAUT2 with Information Quality.

12. Unusan, N. (2006). University students' food preference and practice now and during childhood. Food quality and preference, $17(5), 362-368$.

\section{Author Biography:}

Dr. Ma. Victoria C. Gannaban, LPT, Associate Professor III, Cagayan State University - Andrews Campus, ambicjannie@gmail.com 